\title{
"What Kind of Soviet Citizen Will You Grow into?": Ukrainian Adventure for Adolescents in the Stalinist Epoch
}

\author{
Daria Semenova \\ University of Illinois at Urbana-Champaign
}

\begin{abstract}
This article analyzes a number of Soviet Ukrainian adventure narratives written during the 1930-40s, including the novels "Lakhtak" ("Lakhtak," 1934) and Shkhuna "Kolumb" (Schooner "Columbus," 1940) by Mykola Trublaini, Shkola nad morem (A School by the Sea, 1937) by Oles' Donchenko, Hospodari Okhots'kykh hir (The Owners of the Okhotsk Mountains, 1949) by Ivan Bahmut, and several short stories. This entertaining genre was used to educate its young readers about their place and aims in the world, as well as about the boundaries of the newly-forged Soviet identity and its meaning. This period witnessed a radical change in the criteria for defining group identity, as proposed to young readers: ethno-national markers were substituted by belonging to an ideological community and by class affiliation. As a result, although anyone originating from outside the Soviet borders was perceived as a menace, some foreigners of a "correct political orientation" could be recognized as potentially belonging to "our" community. At the same time, this change implied that there were hidden "enemies" among alleged "in-group" members, which justified the mobilized state of the group identity. The adventure stories analyzed here also shed light on the fostering of a sense of Union-wide unity through the parallels they drew between the experiences of young Ukrainian readers and those of their counterparts in faraway regions of the USSR.
\end{abstract}

Keywords: adventure, Ukrainian Soviet literature, identity, literature for children and youngsters.

0 ne January night sometime in the 1930s, Oleh Bashmachnyi, one of the three 13-year-old protagonists of the novel Shkola nad morem (A School by the Sea, 1937) by Oles' Donchenko, notices a dark silhouette wandering the streets of his native village on the Black Sea shore of the Ukrainian Socialist Soviet Republic. This mysterious figure turns out to be the elderly school gardener, who retained his position as gardener after a former mansion was repurposed into a school. It is hard to say which sounds more sinister: the nickname given to this person, Kazhan (bat), accompanied by demonic stories based on his reclusiveness, or his real name, V"iacheslav Romanovych Dzemydkevych (which indicates a possible, though never articulated, Polish connection) and his former position as a private teacher 
at the mansion. That January night he tried to be inconspicuous as he carried a letter with "unknown foreign stamps" that he had just retrieved from the nearest city's main postal station (Donchenko, Shkola nad morem 347). The vigilant Oleh Bashmachnyi manages to intercept the letter, thus immersing the reader in an adventure in which the school lives of sixth-grade students are intertwined with life-threatening encounters with foreign insurgents. The narrative shows how ideological battles are waged simultaneously against external evils that encroach on Soviet territory from abroad and from internal enemies like Kazhan, and how the plot provides a moral education that will turn the young protagonists into good Soviet citizens. This article describes how these three intersecting conflicts were represented in Ukrainian adventure narratives written during the Stalinist era for young adults and children.

Recent scholarship on Ukrainian literature from the Stalinist period has increasingly focused on the authors of the "Executed Renaissance," the name given to a generation of authors who were prolific in the first decade and a half of the Soviet regime and were repressed during the 1930s. These authors were physically destroyed as human beings - they were sent to labour camps and executed-and their works were erased from the canon of Ukrainian literature. In contrast, this article deals with authors who were widely read, who were promoted by the Soviet state for their didactic function ("recommendable for socialist moral education" was featured on the title pages of some of their books), and whose works were reprinted in multiple editions throughout several decades after their initial publication in the 1930 s or 1940s. Considered remnants of a bygone epoch, Ukrainian adventure narratives compliant with Soviet orthodoxy have been mostly forgotten since the fall of the Soviet Union. However, analyzing these popular texts intended for young adults provides valuable insight into how literature participated in the fashioning of Soviet citizens. I argue that the genre and target audience of these texts made them a powerful cultural mechanism, while contributing to their neglect in scholarship.

There is a tendency to perceive the genre of adventure as something less serious than "real," "high literature," and therefore as something less important. Adventure, even texts that were not originally intended for a younger audience, has long been relegated to the sphere of adolescent reading. By the twentieth century, texts like Robinson Crusoe by Daniel Defoe or Jules Verne's novels were considered to be constructive reading in adolescence, which was never intended by their authors. ${ }^{1}$ However,

1 Martin Green considers Daniel Defoe's novels seminal for the formation of the adventure genre in its modern incarnation, as opposed to medieval and renaissance strains of picaresque adventure novels (Seven Types of Adventure Tale 7). Adventure stories were classically fashioned as boys' reading. However, there is statistical 
contemporary critical thinking about adventure, which has highlighted the possible ideological implications of this entertaining genre, suggests that their relegation to adolescent reading may endow the texts in this genre with greater social, if not literary, significance. Martin Burgess Green explains this importance as follows:

This is a sure mark of relegation to the periphery of literature, though that very shift may be a move to something like the center of culture; for the books that shape ourselves as a nation or as a class are surely the books we read as children. What we read as adults, at least what we read seriously, cannot have that effect, just because serious critical attention disinfects the reading process. (Dreams of Adventure 110)

In contemporary research, adventure stories are believed to be a genre that developed to discursively support imperialist politics and the expansion of European empires. ${ }^{2}$ Scholars tend to focus on the texts written during the peak of overseas colonial expansion (1870-1914) because the subgenre of exotic adventure or "wanderer adventure" (a term coined by Green) developed its classical form during this time. ${ }^{3}$ The ideological functions that recent scholarship identifies include the justification of European empires' overseas colonial politics, and a Eurocentric discourse directed at nonEuropeans who inhabit the "exotic" adventure topoi. At the same time, adventure stories might feature representatives of different European nations and make claims about the superiority of one nation over another, supporting the discursive right of the "superior" nation to rule over colonies. ${ }^{4}$

However, Ukrainian literature did not produce adventure stories during the expansion of European empires. Taking into account the interpretation proposed above, one of the reasons might have been the lack of societal interest in the themes and destinations usually evoked by the exotic adventure genre. The overseas travel that protagonists experienced and the exotic colonies and barbarous locals that protagonists encountered in European adventure narratives had little application to the Ukrainian literary or political situation during the period of 1870-1914. Ukrainian literature was the literature of a nation without its own state, and therefore

research on the dynamics of readership that suggests that, nevertheless, they were usually read just as eagerly by girls, unlike adolescent reading fashioned for girls, which had not been typically read by boys. See Phillips 11, 46-48.

${ }^{2}$ See Brantlinger; Bruzelius; Green; Phillips.

${ }^{3}$ See Green, Seven Types of Adventure Tale 154.

4 For example, Jules Verne criticized British governance over the colonies while ignoring that his native freedom-loving France possessed an equally big colonial empire. In H. Rider Haggard's novels, "British superiority over other peoples is proclaimed, namely the Portuguese" (Pinto Coelho 367). 
with no need to bolster colonial expansion. Ukrainian literature instead reflected its nation's colonized position. It was only after World War I that Ukrainian authors began to write adventure narratives to inform their young readers' mental maps of the world, to shape their values, and to instill in them the ideal of a national ethos.

The conventions of the adventure genre assume a juxtaposition of the "in-group" and the "out-group," that is, "us" and "them," as well as a happy ending and the victory of the group marked as "us." Considering that a genre, and even more so a "formulaic genre" like adventure, is "not just an aesthetic form but also ... part of a group's social contract," these genre conventions are binding (Arens 128). After all, the reader would be disappointed if the text did not reinforce the "in-group" values and way of life by the end of the story. However, when it comes to the principles according to which the "imagined communities" depicted in these narratives are formed, their rigid formulaic structure is in fact rather malleable. ${ }^{5}$

The adventure genre's conventions enable authors to construct narratives that cause their readers to "imagine" their communities along diverse ideological lines. During the Ukrainian revolution in mainland Ukraine (1917-20), in Western Ukraine under the Polish rule during the interwar period (1920s-30s), and in the Ukrainian diaspora throughout the twentieth century, one can trace adventure stories that encourage the young reader to distinguish "us" from "them" along national lines (more or less strictly conceived). The most prominent example of an adventure story of this type is Syn Ukrainy (The Son of Ukraine, 1919, 1946) by Ihor Fediv and Valentyn Zlotopolets', which was written and published during the Ukrainian People's Republic and later re-written for a revised edition published in émigré circles. It constructs national belonging along narrow ethnical lines, and also touches upon issues (obviously much more relevant to the time of its creation in 1919 than to its setting in the seventeenth century) such as the national unity (sobornist') of the Ukrainian lands ruled by different neighbouring states, promoting a vision of the "imagined community" based on the boundaries of ethnic dispersion.

Meanwhile, the same genre form was used to promote a class-based and (allegedly) supra-national identity in Soviet Ukraine. In his book on the creation of the Soviet readership, Evgeny Dobrenko claims that any culture

\footnotetext{
5 Benedict Anderson interprets nations as "imagined political communities-and imagined as both inherently limited and sovereign" (6). Furthermore, Anderson claims that modern discursive forms, such as newspapers and novels on contemporary topics were conducive to the creation of this imagined shared belonging with people whom one had never met. In my analysis of the communities in adventure narratives, I will trace the symbolic and geographical boundaries on which members of the group are separated from non-members.
} 
is formed through the "interaction of production and its consumers; in the process of this interaction, in getting 'used to' each other, they remove each other's 'rough edges' and acquire ... distinctiveness" (The Making of the State Reader 2). However, Dobrenko indicates that this general consideration is especially pertinent in the case of Soviet literature:

The Soviet reader, spectator, or listener is not simply a recipient (or in the Western sense a "consumer of books"): in accordance with the doctrine of "reshaping society" that lies at the heart of Socialist Realism, he is the object of reshaping, "molding." (2)

The role that the Soviet state envisioned for its writers was metaphorically referred to as that of "engineers of human souls," according to the often repeated saying that is usually ascribed to Joseph Stalin, but was initially coined by Iurii Olesha. In this article, I approach adventure narratives from the perspective that Soviet Ukrainian authors intended to "re-forge" or "engineer" their young readers. I consider Soviet Ukrainian adventure narratives from the Stalinist period, including "Lakhtak" ("Lakhtak," 1934) and Shkhuna "Kolumb" (Schooner "Columbus," 1940) by Mykola Trublaini, A School by the Sea (1937) by Donchenko, Hospodari Okhots'kykh hir (The Owners of the Okhotsk Mountains, 1949) by Ivan Bahmut, and several short stories. I argue that these entertaining readings both establish the borders of the imagined community (now encompassing the entire Soviet "people") and define the meaning of belonging to this community.

\section{THE BORDERS OF THE EMPIRE}

Adventure stories are a valuable source to examine boundaries in a given epoch's cultural imagination because of their plot structures, which necessitate a strict distinction between the in-group and the out-group. In Soviet Ukrainian adventure narratives, the borders of the Soviet Union are among the important limits of the imagined community due to the fact that, as Dobrenko claims, "Soviet culture was a culture of inflamed borders" ("The Art of Social Navigation" 186). Meanwhile, cultural and identity differences within the Soviet borders have an entirely different meaning, which I will focus on in a later section of this article. The proximity of the Soviet Union's borders transforms unremarkable villages on the Ukrainian Black Sea shore into spaces of adventure in the novels A School by the Sea by Donchenko and Schooner "Columbus" by Trublaini. The anticipation that everyone outside the Soviet borders is an enemy creates a tense atmosphere in both texts. Neither of the two aforementioned novels identifies the enemies in national or ethnic 
terms, which adds to the generalization that everybody "out there" is an enemy.

In A School by the Sea, the adventure starts with an intrusion from abroad. This transgression of Soviet boundaries occurs first in the form of a letter with foreign stamps and later in the form of a human intruder. Any connection to foreign countries is already suspicious: the foreign stamps on the mysterious letter are a sufficient reason for the adolescent Soviet protagonist (fashioned as an example to same-age readers) to not hesitate in intercepting a letter addressed to someone else. Later on, the impossibility of having innocuous human connections with anybody outside the Soviet Union is reinforced when the young protagonist naively interprets the coded message in the letter as an expectation of the arrival of a "normal brother" ("zvychainyi brat") (Donchenko, Shkola nad morem 483). ${ }^{6}$ The head of the border guard denies such a possibility: "A 'brother'! He had many of them .... Fascist spies, diversionists. A warm familial company" (Donchenko, Shkola nad morem 483). In this type of adventure, no acceptable human relations may connect a Soviet citizen to anyone abroad, and the existence of any such connection would cause deep suspicion. Furthermore, any foreigner is automatically perceived as an evil-doer and an enemy of the Soviet state, since the only foreigners that are depicted in the novels are the ones who have penetrated the Soviet borders. In other words, the adventure narrative represented in A School by the Sea by Donchenko and Schooner "Columbus" by Trublaini overlooks the existence of peaceful and even oppressed labourers among the residents of foreign countries.

Trublaini's Schooner "Columbus" uses a plot structure similar to the plot in A School by the Sea. Here, too, the specific origin of the foreign insurgents remains unnamed, but only for the reader, which makes this strategy even more evident. Donchenko's protagonists did not understand what country issued the unknown foreign stamps, but the antagonists in Schooner "Columbus" speak "some foreign language" ("iakoius' chuzhoiu movoiu") that one of the protagonists understands and their insignia are eventually recognized as belonging to what is called "a state known for its aggressiveness" ("vidomoi ahresyvnoi derzhavy") $(315,306)$. For the reader, however, their identity remains undefined. The foreigners' interests are described in Trublaini's text with greater specificity than in Donchenko's novel. In Trublaini's novel, the object of contention is a natural resource found on a coastal island in the Black Sea, which might benefit Soviet technological development and become an asset in the anticipated war (as the mood of the 1930s reflected). ${ }^{7}$

\footnotetext{
${ }^{6}$ All translations are my own.

7 The four parts of the novel were written and published separately starting in the
} 
Another common feature in the depiction of the opposition between the true members of the in-group and both hidden inner enemies and foreign agents in the novels by Donchenko and Trublaini is that the horizontal, territorial division that separates the Soviet Union from other countries is reinforced by a temporal division, which distances the Soviet Union from its territory's history. Hidden inner enemies, such as Donchenko's Kazhan, mentioned earlier, and a similar figure in Trublaini's novel, Koval'chuk (more on whom later), are recognizable because of their erroneous political affiliations in the revolutionary or pre-revolutionary past. The main antagonist in Trublaini's novel, Anch, who is supposed to infiltrate the Soviet Union and disrupt the development of the resource-rich island, is qualified to do so because he lived in the Russian Empire before the Revolution of 1917.

Unlike the two novels analyzed above, Trublaini's "Lakhtak" is set on a Soviet ship during its unplanned overwintering in the Laptev Sea, where its crew encounters a mysterious foreign ship. Prior to their identification, the Soviet sailors perceive the "Others" as being ominous: "Is it possible that this is a foreigner: a German, an Englishman, an American?-contemplated the hunter" (Trublaini, "Lakhtak" 92). As the Soviet protagonists get acquainted with some of the sailors from the Norwegian ship, another criterion of differentiation between "us" and "them" important for Soviet discourse emerges, that is, class affiliation. It turns out, quite in line with the dominant ideology, that only the skipper (i.e., somebody in a ruling position) is hostile to the Soviet sailors. The common crew-members are proven to be good men, and one of them even joins the Soviet ship crew in the end; that is, he is embraced as a potential member of the in-group based on his class affiliation.

As I have shown, the "others" are represented as unambiguously hostile, ideologically alien, and ill-willed when they enter what is perceived to be a part of one's "own" symbolic space. The situation in "Lakhtak" is complicated by the fact that the Soviet sailors consider the Arctic seas, where the plot takes place, a part of their "own" territory with its resources belonging unequivocally to the Soviet people. ${ }^{8}$ The Norwegians, however, believe that

late 1930s and continuing during World War II, although Soviet participation in said war is totally ignored in the text. As a result, there is an increasing feeling of turmoil and violence as the novel proceeds from one part to another; yet, following the convention of the adventure genre, by the end of the novel the Soviet youths (two girls and a boy) succeed in saving their community and country from the evil-doers and the surviving two of them construct peaceful plans for themselves. Trublaini died in 1941, during the first months of the Soviet-German conflict while serving as a war journalist, and his text was posthumously edited to keep one of the heroines alive and make it possible for her to join the Komsomol as well.

8 The Soviet Union declared the Arctic seas its possession from the state borders to 
they are acting in neutral waters, which are grounds to "acquit" at least some of them as earnest workers and not evil-intentioned foreigners.

In all the cases described above, the borders of the Soviet Union remain the most important demarcating lines, both in delineating space and in marking affiliation to the in- or out-group. In the novels analyzed so far, adventure and an encounter with the "other" takes place in the symbolically native space (whether or not the "other" consents to such appropriation). There is an interesting difference in this regard between Ukrainian Soviet literature and Russian Soviet literature. Researchers of Russian Soviet adventure narratives from the 1920s and 1930s notice a change between the two decades. In the 1920s, the protagonists of adventure stories tended to bring the Soviet system of values to the "others," whereas encounters with "others" who penetrate the Soviet space predominate in the 1930s (Lupanova 166; Maslinskaia 237). This abrupt genre change is consistent with the general understanding of the shift that happened in the Soviet culture of the 1920-30s: "drawing away from internationalism ... [for the sake of] 'socialism in one country,' that is, the doctrine that it is possible to pull off a socialist revolution in a single country, such as Russia, without a broader proletarian revolution" (Clark, Moscow, the Fourth Rome 7).

In comparing Malinskaia's observation about the shift in Russian Soviet adventure stories to the Ukrainian context, one can see that the use of these two motifs, exotic and domestic adventure, is quite different. While the aforementioned Ukrainian novels by Donchenko and Trublaini, which were written in the 1930s, illustrate the second motif, the first motif is only marginally present in Ukrainian Soviet literature. Adventure using the first motif, with Soviet protagonists venturing to foreign exotic lands, was still available to the Ukrainian reader in translations from Russian Soviet literature, including texts in which the reader was told about the adventures of Ukrainian adolescents, along with adolescents from other parts of the Soviet Union, such as in Vokrug sveta v 50 dnei (Around the World in Fifty Days, 1928) by Iakov Kal'nitskii and Vladimir Iurezanskii. ${ }^{9}$ However, no original adventure stories in this vein are known in Ukrainian Soviet literature from this period. This difference makes one think tentatively about the politics that determine which members of the Soviet community are allowed to act as mouthpieces for even a state-sponsored message, especially

the North Pole. Exploration of the Arctic was a significant theme in the public discourse of the 1930s. The sub-polar land area, the seas, and the North Pole itself were considered "the country's last terra incognita, its final blank space on the map" and a chronotope for the new Soviet man to show his best qualities (McCannon 242). This novel by Trublaini draws heavily from this mythology.

9 Published in Russian and simultaneously in Ukrainian with no marking on the edition that it was not an original. 
since any differences within this community are diminished at an explicit level, as I explore further.

\section{Porous Communities}

As I have shown above, the shift to class and ideological affiliation as the criteria (as opposed to national and ethnic criteria) that constitute the imagined communities of the "in-group" and the "out-group" allows for the possible inclusion of those who are outside of the imagined community because of their foreign origin. Moreover, the ideology of world communist revolution that anticipated more countries establishing socialist regimes and becoming Soviet republics, views this inclusion as a necessary and impending process. However, the imagined community's constitution via class and ideological affiliation also allows for the possibility of discovering "alien elements" among alleged members of the in-group. I will consider two aspects of this failure to correspond to the ethos of Soviet identity: the first relates to "passing" for a loyal in-group member by an adult, while the second concerns the cultivation in children and adolescents of the qualities necessary to be true Soviet citizens.

There is always the potential to discover a class enemy disguised as "one of us," and these internal enemies can be more or less conspicuous. In Oles' Donchenko's novella Rozviduvachi netriv (The Explorers of the Wilderness, 1934) the antagonists are clergy members hiding in the taiga. They are not only the enemies of the Soviet youths exploring the forest, they are also the enemies of all the progress represented by the Soviet system. They do not disguise their class or ideological affiliations in any way, which immediately makes their hostility obvious. A plot twist in which the words or actions of someone assumed to be a member of the community betray his or her alterity is an effective narrative strategy in adventure stories. In "Lakhtak," in a moment of crisis three members of the crew reveal their true nature as class and ideological enemies. Unlike the rest of the exemplary crew, they endeavour to exploit resources that can lead to personal gain, such as gold and fur, instead of resources that will bring general prosperity, like oil. They question the need to sacrifice their personal comfort for the common good, which is taken for granted by the exemplary Soviet sailors. To make the message to the young reader definitive, the author describes the outcomes of pursuing these two systems of values: "our" crew members remained healthy and benefitted the country as a whole when they spent the winter in the Laptev Sea, while the "renegades" developed scurvy.

This juxtaposition might make it seem as though affiliation with the ingroup is a matter of choice. However, this is not the case in Soviet adventure narratives, because tell-tale signs always expose the fact that someone is not 
"one of us." People are defined by their choices: not by present choices but by past choices, and those choices cannot be undone. For instance, Koval'chuk's choice of the "wrong side" in the revolutionary struggle of 1918 in Trublaini's Schooner "Columbus" and Kazhan's affiliation to the old landowner in Donchenko's A School by the Sea, as shown below, cannot be reversed, since they are perceived as a manifestation of their nature, which cannot be changed.

There is something suspicious about Kazhan from the very first moment he is introduced: he fails to act as a proper member of the community, and his reclusiveness and secretiveness engender two sets of suspicions that he has an immoral nature. His nickname ("bat") reflects the village inhabitants' rumours about him that draw from folk demonology, and his outer appearance reinforces this demonic discourse: "He had large ears and sharp eyes under hairy eyebrows. Bushes of hair looked out from his sharp nose, from his ears, grew on his bony fingers" (Donchenko, Shkola nad morem 491). A second set of beliefs about Kazhan's flawed nature is grounded in Soviet ideology. He is too secretive to be a proper member of the collective; he evidently has something to hide because no one knows why he chooses to walk many kilometres to the city, suggesting that he does so to participate in an activity frowned upon by Soviet ideology-to go to church. Rumours about his connections to the former mansion owner and his possibly Polish last name add to this suspicion. Although the two discourses (folk demonology and Soviet ideology) seem opposed to one another and the progressive younger villagers mock the old women's rumours about Kazhan's demonic nature, both means of characterizing Kazhan's transgressive nature are reliable. Since the narrative later reveals Kazhan's anti-Soviet activity and his role in helping foreigners, all the sightings of him that engendered superstitious rumours receive explanations within the discourse of anti-Soviet crimes.

The fish inspector Koval'chuk in Trublaini's Schooner "Columbus" tries harder to belong or to seem to belong to the Soviet community of the island, yet tell-tale signs of his inherent wrongness betray him. Trublaini provides the reader with a more psychologically complex depiction of his "internal" antagonist than Donchenko provides for his. Trublaini shows that Koval'chuk somewhat unwillingly collaborated with foreign invaders because they blackmailed him with evidence of his non-Bolshevik affiliation during the revolution, which "will not be excused" by the Soviet regime (Trublaini, Schooner "Columbus" 234). This additional level of complexity makes this character's biography and motivations closer to the actual historical experience of his generation, whose representatives had to work hard to prove to the regime their adherence to orthodox Soviet ideology. This was especially true if they were unlucky enough to have expressed unorthodox political beliefs before, during, or just after the revolution, when the window 
of historical possibilities had not yet closed.10 Even with these added psychological insights, other signs of Koval'chuk's crookedness, such as his bad treatment of his daughter, indicate that it is only natural to expect him to commit state treason. In short, despite the different level of psychological complexity in the description of the "inner enemies" in Donchenko's and Trublaini's novels, both of the antagonists are portrayed as being bad by nature, which manifests in their past choices and political affiliations. Their efforts to mimic proper action and belief will only delay the inevitable exposure of their evil natures.

Choice and personal efforts matter only in the second aspect of the "porosity" of the in-groups, that is, the necessity of cultivating the proper qualities to be a good Soviet citizen. In this aspect, the adolescent protagonists of adventure narratives model the formation of correct beliefs and growth into worthy Soviet citizens for the adolescent readers of such texts. Tellingly, a 13-year-old protagonist of A School by the Sea (and, simultaneously, the story's reader of approximately the same age) is posed the question: "What kind of a Soviet citizen will you grow into?" (Donchenko, Shkola nad morem 491). ${ }^{11}$ Donchenko's novel as a whole is especially illustrative of the didactic function of adventure narratives, revealing this genre's connection to the Bildungsroman genre, which results whenever the protagonists of the modern adventure are children, adolescents, or young adults. ${ }^{12}$ In the course of the novel, three 13-year-olds learn important lessons that will facilitate their growth into exemplary Soviet citizens while they fight a foreign insurgent. Sashko Chaika's understanding of personal development becomes more complex and he decides to develop not only his poetic skills, but also his physical fitness; Halyna Kukoba learns to not let personal emotions affect the interests of the collective; and Oleh Bashmachnyi learns to abandon his futile dreaminess and to pursue goals approved by authoritative adults. As with the adults described above who are suspicious when they seem to be insufficiently a part of the collective, young Soviet protagonists' ideological upbringing is, first and foremost, about belonging to a collective, and about considering collective goals as a priority over personal feelings. An immediate collective, such as a school

\footnotetext{
${ }^{10}$ Considering authors' biographies is outside the purview of this article, but it might be argued that, in creating these texts that are highly in-line with orthodox Soviet ideology, some of these authors might have been trying to prove their belonging.

${ }^{11}$ Literally, "will grow out of you" ("Iakyi hromadianyn Radians'koho Soiuzu z tebe vyroste?"), as if it was an act of a different subjectivity.

12 This connection between the genres also applies across the ideologies chosen by the authors: a young protagonist might have to "grow up" to become a worthy representative of his nation, imagined along the lines of the ethno-cultural tradition, or as a member of the supra-national Soviet people, as in this example.
} 
class, is an intermediate step through which the adolescent protagonists from the small village become members of a larger collective comprised of worthy representatives of the Soviet people, and where the student learns to align his/her actions and goals with the goals of the community.

Thus far, I have considered the identities represented in Soviet Ukrainian adventure stories in terms of how the in-group within the Soviet Union is opposed to the out-group outside of its borders. I have shown that this strict horizontal opposition is modified by the criteria of class and ideology, and that ostensible in-group members might be revealed to be internal enemies. Additionally, these criteria enable some foreigners to be included in the ingroup based on their class affiliations and beliefs. In the final part of my article, I investigate another aspect of in-group imagery: how adventure stories gloss over the enormous cultural differences between the diverse peoples allegedly embraced by the newly-created Soviet identity.

\section{THE BROTHERHOOD OF PEOPLES}

The novels and stories presented here are texts representing Ukrainian Soviet literature. They were written in Ukrainian, and they were intended for Ukrainian adolescent readers. Proper names and names of localities suggest that the events in A School by the Sea by Donchenko and Schooner "Columbus" by Trublaini happened somewhere in the territory of the Ukrainian Soviet Socialist Republic, and the characters pertain to Ukrainian adolescents, but this is never stated explicitly. For example, in Donchenko's novel, the word "Ukrainian" appears only a few times. It is used as an adjective three times, in each case referring to the school subject of Ukrainian language and literature. The teacher who teaches it is an important role model for the youths. This particular subject (Ukrainian language and literature) is a focus in the story because it is the basis of proper reading practices for loyal Soviet adolescents. The only time that the word "Ukrainian" appears as a noun is in the description of the diversity of the in-group that the protagonists save from the foreign menace:

letters from all ends of the boundless country started to arrive. The letters came from Moscow, from Kyiv, from Vladivostok, from Tashkent, from Minsk.... Those who wrote were pioneers from the far-away Kazakhstan and from the cold shores of the White Sea, they were soldiers in the Red Army and pilots, they were professors and workers, Russians and Ukrainians, Uzbeks and Georgians, Bashkirs and Tatars . . . (Donchenko, Shkola nad morem 538)

One might appreciate the careful construction of the hierarchy among the different subgroups within the Soviet Union, expressed in the order of the 
list of nationalities and the cities they inhabited. "Russians," "the elder brothers," are mentioned first, then three more "titular nations" of the Soviet republics are listed, followed by two "titular nations" of national republics within the Russian Socialist Federative Soviet Republic. This novel was published in 1937, which is after a significant shift, dated by historians as taking place in the mid-1930s, when, as Jonathan Platt has stated,

the "affirmative action" [as coined by Terry Martin] of the first fifteen years of Soviet rule-which promoted the national identities of even the smallest ethnic groups to the detriment of "great Russian chauvinism" - [was replaced by] the new "friendship of peoples" policy [that] limited the number of national units and firmly positioned the Russians at the center of the Soviet polity as "first among equals." (8)

In fact, in several texts written during this period, Ukrainian authors depict adventure in the vast territories of the Soviet Union, without explicitly comparing or connecting these locations to the experiences that their imagined Ukrainian reader might have. Let us dwell for a while on this subcorpus of prosaic texts that lack Ukrainian specificity, which, to my mind, all follow the same pattern.

The scheme of this type of adventure narrative can be summarized as follows: people of a specific nationality live according to their traditional ways, the good people are uneducated and poor, while the rich people and/or representatives of the clergy oppress them. Someone who represents the centre of the Soviet Union, or a local who has experienced the larger world and learned communist ideology, arrives to disturb this picture. After a series of breathtaking adventures, this figure helps to establish justice and a new social order in which the liberated honest labourers live happily ever after. This aspect of the narratives is consistent with the history of the genre; that is, from when it discursively supported Western European colonial projects, despite the Soviet disavowal of imperialism as pertaining to ideological enemies. In classical adventure stories set in exotic locations, it is also common for a hero who represents the ideological centre to arrive, to help save the locals from themselves, and to establish a just social order bound to the centre's (metropoly's) ruling over the "backward" locals. The difference lies in the Soviet narratives' attempt to show that the "common labourers" of the exotic nationalities might have more in common with toilers of other Soviet nationalities than with the "exploiters" from among their own kin. This plot scheme resonates with Katerina Clark's idea about the spatial organization of socialist realism across the arts: "[a]t the heart of ... socialist realism lie spatial myths in which 'heroes' or 'leaders' function as human embodiments of, or emissaries from, a higher-order space" ("Socialist Realism and the Sacralizing of Space" 3-4). In the case of literature, this implies that 
at the level of deep structure, the hero's mission is not ultimately his public task to build that power station, raise those economic yields, or drive out that enemy, not even just to grow as a communist, but to mediate between two different orders of space that might somewhat tritely be classified as the sacred and the profane. (Clark, "Socialist Realism and the Sacralizing of Space" 4)

The novel The Owners of Okhotsk Mountains (1949) by Ivan Bahmut is a clear-cut example of this pattern. This text is a temporal outlier, as it was created in the later part of the Stalinist period. Yet the events described in this adventure novel take place in the 1930s, as do the sensibilities and ideologies that the novel reflects. Bahmut tells the story of a Ukrainian boy named Iura who travelled with his father, a sea captain, and was accidentally left behind on the shore of the Okhotsk Sea. Unable to return to civilization, Iura joins a family of Orochi deer keepers, who only occasionally visit the shore, and who contact representatives of the Soviet state only to exchange the furs they collect as they roam with the deer. However, Iura learns that the common Orochi, like the ones he travels with, do not own their herds; instead, they work for a small group of rich people in their tribe who own all the deer and other resources. These rich tribal members use their power to keep their poor compatriots from starting their own herds and freeing themselves from exploitation. The shaman of the tribe uses his dominant position and the common people's belief in the spirits to reinforce this classic capitalist oppression. Apart from that, the rich Orochi-the internal enemyare supported by an external enemy, the Japanese, who are interested in using this anti-Soviet outpost for their own purposes. Ultimately, Iura and several conscientious Orochi manage to overturn the situation, overcome the oppressor's discursive power, and establish a just, socialist society, in which the Orochi will be the true owners of the Okhotsk mountains and all the resources therein, as the title of the novel hints at.

Additional examples of this plot type can be found in the novella about Kazakhs, Aul Irhiz ("Yrgyz Aul," 1932) by Donchenko, and in Trublaini's series of short stories for children, including "Malyi poslanets'" "The Young Messenger," 1933) and "Kryla rozhevoi chaiky" ("The Wings of the Red Seagull," 1934) that are about the Chukchi and the Eskimos. As if to highlight the schematic character of this plot, the pattern is repeated twice in Trublaini's short stories: first, a Chukchi community is "saved" by a Soviet from the mainland, and, in a second story, an Eskimo community is "saved" by the Chukchi girl who was the protagonist in the first story.

It is typical of any adventure story to depict protagonists who overcome increasingly dangerous obstacles while proving their bravery and other virtues, thus demonstrating that they are worthy of a prize. In the stories mentioned above, the obstacles that the protagonists encounter are associated with the wily representatives of the pre-Soviet village or tribal 
elites, that is, the rich people and/or the spiritual leaders (including clergy and shamans). These pre-Soviet elites are economically interested in the preservation of the old way of life and oppose the social and scientific progress associated with Soviet rule, out of mere greed. The state-sponsored message and the generic form fit well together, so the plot can be (and was) retold again and again about different national groups or tribes in the Soviet Union. As the scholarship has shown, the early decades of the Soviet regime witnessed a proliferation of nations and nationalities, support for the development of local languages, and the fostering of local elites' participation in local governance as a part of the korenizatsiia (nativization) policy. It was suggested that national form-each community's first language-is necessary for the socialist content to be disseminated to the heterogenous populations in all parts of the Soviet Union, including the most "backward" ones. Although the Ukrainian adventure stories analyzed here are not texts that propagate the socialist message in various languages, they reflect this imperative process of dissemination in their narratives. The fact that it is possible to distinguish a uniform scheme, as I have shown above, is due to the requirement of a uniformity of "socialist content," only tinted with local colouration (the types of work people of the community do; whether their class enemies will include animistic shamans or representatives of an established monotheistic religion). According to Yuri Slezkine, since at least 1928, the discourse on national policies presupposed that "all nationalities without exception had to produce their own exploiters, heretics, and antiSoviet conspirators," an endeavour reflected in the examples of adventure prose (440).

The young reader encountered narratives about adventures of a young protagonist in various parts of the Soviet Union alongside stories containing more detail specific to the Ukrainian context. The latter type of story was represented in the novels by Trublaini and Donchenko discussed earlier in this article. Here, somewhere in the Ukrainian Socialist Soviet Republic, a setting more familiar to the Ukrainian reader, young protagonists confronted those interested in preserving or restoring the pre-Soviet order. In the case of adventures featuring protagonists from various Soviet nationalities, the unfamiliar cultural context of the narratives enabled the authors to explicate the ideologeme in a "clearer," untainted form. The dramatic "conflict of the classes" could unfurl countless times in a sanitized form. Namely, the exotic locations allowed the authors to avoid a juxtaposition of the official Soviet historical narrative with conflicting versions of local history provided by family, etc. These texts obscure the complications of the Soviet rise to and consolidation of power, including the years-long violent events that accompanied the dismantling of Russia's monarchy, the annexation of territories, and the creation of the Soviet Union, of which to some degree the young readers would have been aware. Instead, this type of adventure story 
represents the upheaval of a civilization in an idealized, fantasized fashion in which the "just" socialist order replaces the "unjust" traditional one as effortlessly as if a magician had waved a magic wand.

By familiarizing young readers with their peers in remote places, these adventure narratives extended the notion of the "in-group" to incorporate the entire "imagined community" of the Soviet Union. Despite their disparate depictions of everyday life, these texts suggested that Ukrainian readers and the exotic protagonists had similar experiences in the most significant aspects of life-Soviet ideology and way of life. In other words, adventure narratives promoted the "brotherhood of peoples" and furthered the creation of the Soviet nation.

Earlier I mentioned that a representative of the Soviet centre interferes in these peripheral communities to establish a "just" social order. An example of such interference is depicted in Bahmut's novel, The Owners of the Okhotsk Mountains, where a Ukrainian boy helps the Orochi. From the boy's Ukrainian last name-Zub-we may deduce that he is Ukrainian, ${ }^{13}$ but the Orochi cannot make this distinction and refer to his nationality as Russian ("rus'kyi"):

"Let us wait until spring," said Byiakan, "there are many Russians on the shore, they will help, it is scary without them."

"We have a Russian," answered Illia, pointing at Iura.

Kuz'ma nodded with energy and joy:

"Let us not wait until spring. We have a Russian!" (Bahmut 64)

The same confusion and lack of explicit Ukrainian identity can be seen in other Ukrainian Soviet adventure narratives. Often, we can infer that the protagonists are Ukrainian only from their last names, and from the facts that

\footnotetext{
13 Admittedly, "Zub" can also be a Russian last name. However, it is much more common for Russian last names to have standard suffixes, "-ov" and "-in," while it is more common for Ukrainian last names to be derived from nicknames without added suffixes. Using an ambiguous last name instead of one with a clear Ukrainian suffix like "-enko" or "-chuk" or one with a clearly Russian suffix leaves space for interpretation. Moreover, the author interchangeably uses two short versions of the protagonist's first name, Iurii: "Iura" (traditional Russian but used by many Soviet Ukrainians) and "Iurko" (traditional Ukrainian), with, admittedly, a statistical preference given to the first version. This might be a conscious authorial strategy for creating a character ethnically non-particular but potentially more relatable to the Ukrainian reader than somebody with an unambiguously Russian-sounding name. For example, Donchenko's novella The Explorers of the Wilderness, mentioned earlier, features precisely such unambiguously Russian protagonists exploring wilderness in a remote part of the Soviet Union. The subtle difference between the two cases is quite illustrative of the measure to which it was allowable to be overtly Ukrainian in the post-korenizatsiia period.
} 
they live in the Ukrainian Socialist Soviet Republic and study Ukrainian literature at school.

To comply with censorship, the texts cannot mention that the protagonists "are" Ukrainians because a good Soviet protagonist and role model for young readers must not have a prominent ethno-national identity. For the discourse of Soviet adventure, the salience of a character's ethnonational identity either marks enemies of the Soviet regime or marks socalled "backward" peoples, who have come into contact with Soviet society and have been included in the orbit of Soviet interests, like the Orochi, the Chukchi, or the Eskimos in the stories discussed above. I suggest that the exotic peripheries of the Soviet Union were safer settings than Ukrainian soil for authors like Trublaini and Bahmut. While focusing on ethnicities for which it was acceptable to have ethno-national identity, the authors avoided censorship. In her chapter on the Ukrainian writer and film director Oleksandr Dovzhenko, Lilya Kaganovsky illuminates a similar dynamic in her analysis of his two first sound films from the 1930s. Although quite orthodox in its socialist message, Dovzhenko's first sound film in Ukrainian was condemned as "nationalistic" based on his choice of language, after which the director turned to the topic of the Soviet conquest of the Far East in his Russian-language Aerograd (Air City) to avoid "'politically suspect' Ukraine" (Kaganovsky 163). Although the texts analyzed in this article were chosen based on their compliance with and success in reproducing Soviet ideology, this compliance may not be the result of the authors' untainted belief but a result of their conscious selection of topics and locations that would be ideologically safe for their adventure prose. Bahmut spent the second half of the 1930s as a political convict in the Soviet labour camps, having been falsely accused of "counter-revolutionary activity." It is only because he survived this experience that one can analyze his postwar prose, which contains prominent examples of adventure stories that educate young Ukrainian readers to be proper Soviet citizens. His pre-arrest prose reflected an individual who was a marginal member of the "executed Renaissance."

\section{CONCLUSIONS}

The genre form of adventure stories used in the Soviet Union, particularly in Ukrainian Soviet literature, was refashioned to suit Soviet, rather than imperialist, ideology. In particular, adventure narratives instilled Soviet identity and ethos in their young readers, while also promoting an image of the "imagined community" of "Soviet people."

Several specific textual strategies facilitated the construction of the Soviet imagined community. The structure of the adventure genre was used to enforce the strict opposition of "us" within Soviet borders vs. "them" 
outside, however, leaving an opportunity to enlarge the Soviet "family of nationalities" after the world revolution. At the same time, differences within the borders of the Soviet Union were obscured to the greatest possible extent. The protagonists were not allowed to have any ethno-national peculiarities if they were assumed to be Ukrainians. A realization of the formula of socialist realism- "national in form, socialist in content" (as proclaimed by Joseph Stalin) - was evident to the reader only when the authors related adventures in remote places of the Soviet Union.

These adventure stories of the Stalinist era promoted a highly mobilized Soviet identity. All the aforementioned texts express a high degree of anxiety about the possibility of "alien elements" disguising themselves as the members of one's "own" imagined community. Through the young protagonists, these texts attempted to inform young readers about the orthodox interpretation of Soviet identity. Together with texts aimed at adult readers, these narratives participated in the promotion of a Soviet identity among the diverse populations from which the "Soviet people" were to be created. Written in Ukrainian, they obscured any sign that they belonged to the national literary tradition. Only two things remained distinctive to this dissemination of Soviet "socialist content": the vehicle (the language), and the addressee (the young person who was to be molded into a good Soviet citizen).

\section{Works Cited}

Anderson, Benedict. Imagined Communities: Reflections on the Origin and Spread of Nationalism. Verso, 1991.

Arens, Katherine. "When Comparative Literature Becomes Cultural Studies. Teaching Cultures through Genre." The Comparatist, vol. 29, 2005, pp. 123-47.

Bahmut, Ivan. Hospodari Okhots'kykh hir. Vydavnytstvo TsK LKSMU “Molod'," 1951.

Brantlinger, Patrick. Rule of Darkness: British Literature \& Imperialism, 1830-1914. Cornell UP, 1990.

Bruzelius, Margaret. Romancing the Novel: Adventure from Scott to Sebald. Bucknell UP, 2007.

Clark, Katerina. Moscow, the Fourth Rome: Stalinism, Cosmopolitanism, and the Evolution of Soviet Culture, 1931-1941. Harvard UP, 2011.

---. "Socialist Realism and the Sacralizing of Space." The Landscape of Stalinism: The Art and Ideology of Soviet Space, edited by Evgeny Dobrenko and Eric Naiman, U of Washington P, 2003, pp. 3-18. Studies in Modernity and National Identity.

Dobrenko, Evgeny. "The Art of Social Navigation: The Cultural Topography of the Stalin Era." The Landscape of Stalinism: The Art and Ideology of Soviet Space, edited by Evgeny Dobrenko and Eric Naiman, U of Washington P, 2003, pp. 163200. Studies in Modernity and National Identity.

---. The Making of the State Reader: Social and Aesthetic Contexts of the Reception of Soviet Literature. Stanford UP, 1997. 
Donchenko, Oles'. Aul Irhiz. Tvory v shesty tomakh, vol. 1, Molod', 1956, pp. 109-82.

---. Rozviduvachi netriv. Tvory v shesty tomakh, vol. 2, Molod', 1956, pp. 5-72.

---. Shkola nad morem. Tvory v shesty tomakh, vol. 2, Molod', 1956, pp. 343-543.

Green, Martin Burgess. Dreams of Adventure, Deeds of Empire. Routledge and Kegan Paul, 1980.

---. Seven Types of Adventure Tale: An Etiology of a Major Genre. Penn State UP, 1991. Kaganovsky, Lilya. The Voice of Technology: Soviet Cinema's Transition to Sound, 19281935. Indiana UP, 2018.

Lupanova, Irina. Polveka: Sovetskaia detskaia literatura: 1917-1967. Detskaia literatura, 1969.

Maslinskaia, Svetlana (Leont'eva). "Pionerskaia belletristika vs. bol'shaia detskaia literatura." "Ubit' Charskuiu...": Paradoksy Sovetskoi literatury dlia detei. 1920-e1930-e gg., edited by Valerii V'iugin and Marina Balina, Aleteiia, 2014, pp. 23145.

McCannon, John. "Tabula Rasa in the North: The Soviet Arctic and Mythic Landscapes in Stalinist Popular Culture." The Landscape of Stalinism: The Art and Ideology of Soviet Space, edited by Evgeny Dobrenko and Eric Naiman, U of Washington P, 2003, 241-60. Studies in Modernity and National Identity.

Phillips, Richard. Mapping Men \& Empire: A Geography of Adventure. Routledge, 1997.

Pinto Coelho, Maria Theresia. "The Image of the Portuguese in the British Novel of Empire: King Solomon's Mines and Prester John." Colonizer and Colonized, edited by Theo D'haen and Patricia Krues, Rodopi B.V., 2000, pp. 357-69.

Platt, Jonathan Brooks. Greetings, Puskin!:Stalinist Cultural Politics and the Russian National Bard. U of Pittsburgh P, 2016.

Slezkine, Yuri. "The USSR as a Communal Apartment, or How a Socialist State Promoted Ethnic Particularism." Slavic Review, vol. 53, no. 2, 1994, pp. 414-52.

Stalin, Iosif (Joseph Stalin). "Politicheskii otchet Tsentral'nogo Komiteta XVI s"ezdu VKP(b) 27 iiunia 1930 g." Sochineniia, vol. 12, Gosudarstvennoe izdatel'stvo politicheskoi literatury, 1949, pp. 235-373.

Trublaini, Mykola. "Kryla rozhevoi chaiky." Veselka, 1982.

---. "Lakhtak." Shkhuna "Kolumb": povisti, opovidannia, Radians'ka shkola, 1989, pp. 3194.

---. "Malyi poslanets'." Veselka, 1976.

---. Shkhuna "Kolumb." Shkhuna "Kolumb": povisti, opovidannia, Radians'ka shkola, 1989, pp. 195-512. 